\title{
Contribution to the Epidemiological Study on the Main Pathologies of Ruminants Declared in the Central Slaughterhouse of Jijel (Algeria)
}

\author{
Mourad HAMIROUNE ${ }^{1 *}$, Mohamed DAHMANE², Hadjer CHENIGUEL ${ }^{2}$, Amina CHAREF², Abdelhamid \\ FOUGHALIA ${ }^{3,4}$ \\ ${ }^{1}$ Department of Agro-Veterinary Sciences, Faculty of Nature and Life Sciences, Ziane Achour University, \\ Moudjbara Road, BP 3117, Djelfa, Algeria. \\ ${ }^{2}$ Slaughterhouse of Jijel, Cité Arrabta, 18000 Jijel, Algeria. \\ ${ }^{3}$ Laboratory of Microbial Ecology, Faculty of Nature and Life Sciences, Abderrahmane Mira University, \\ Béjaia, 06000, Algeria. \\ ${ }^{4}$ Center for Scientific and Technical Research on Arid Regions, University Campus, B.P. 1682, R.P Biskra, \\ 07000, Algeria. \\ *corresponding author: mouradhamiroune@gmail.com
}

Bulletin UASVM Veterinary Medicine 76(2)/2019

Print ISSN 1843-5270; Electronic ISSN 1843-5378

doi:10.15835/buasvmcn-vm:2019.0021

\begin{abstract}
:
In order to assess the epidemiological situation of certain infectious and parasitic diseases of ruminants, a study was carried out in the central abattoir of Jijel on 625 animals (511 cattle, 74 sheep and 40 goats).

The results showed that the overall organ contamination rate by the pathologies studied was $17.12 \%$ with a higher prevalence rate for fasciolosis (12.32\%) compared to other pathologies. In addition, the lungs are contaminated with abscess and hydatidosis (3.04\% and $0.48 \%$, respectively), whereas the liver is mainly affected by fasciolosis, abscess and hydatidosis $(12.32 \%, 0.64 \%$ and $0.48 \%)$, respectively) and the kidneys are affected only by cysts $(0.16 \%)$. In parallel, the liver is more contaminated $(13.44 \%)$ compared to the lungs $(3.52 \%)$ and the kidneys $(0.16 \%)$. In addition, with the exception of two weak positive correlations between hydatidosis and temperature $\left(\mathrm{r}=+0.01689, \mathrm{R}^{2}=+0.00029\right)$ and between abscesses and precipitation $\left(\mathrm{r}=+0.27335, \mathrm{R}^{2}=+0.07472\right)$, other high positive and negative correlations were observed between the rest of the pathologies and mean values of temperature and precipitation. Therefore, it is necessary to implement an extension program of all stakeholders in the industry in order to avoid significant economic losses and preserve consumer health.
\end{abstract}

Keywords: epidemiology, ruminants, factors of variation, economic losses, Jijel

\section{Introduction}

Meat, like any edible food, has a place in the human diet (Lecerf, 2014). Like other sources of animal protein, its amino acid composition is quite satisfactory because it contains all the essential amino acids (Lecerf, 2014). It is considered a food of choice because of its nutritional value. Its high protein content and the nature of these proteins make it an essential food for a balanced diet (Bender, 1992).

The public is entitled to expect that the food they consume is safe and suitable for consumption. Food poisoning and food-borne diseases are at 


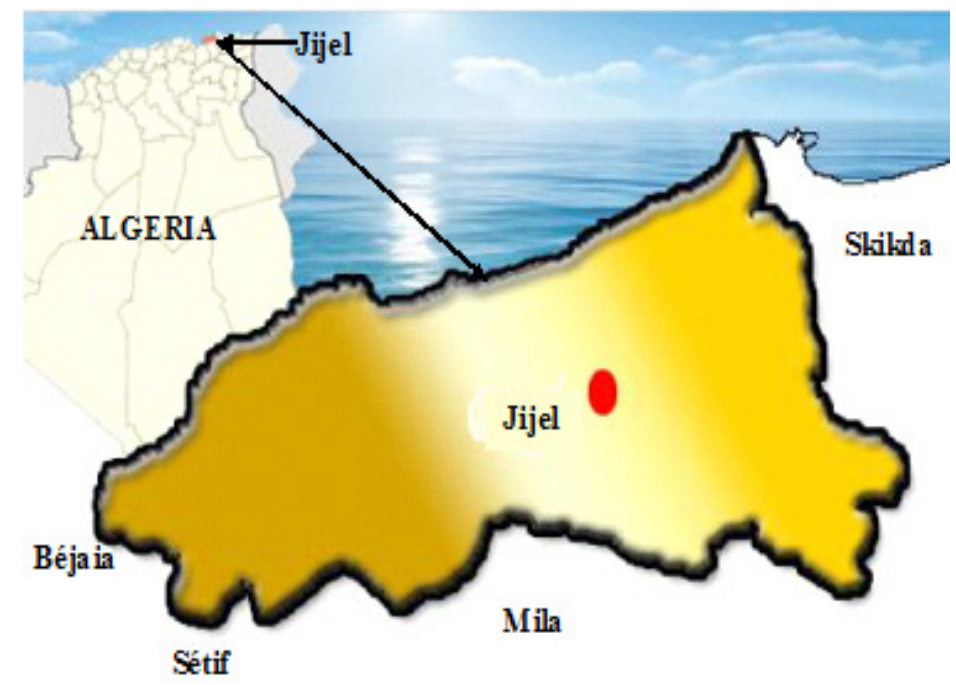

Figure 1. Geographic location of the wilaya of Jijel (ANDI, 2013)

best unpleasant; at worst, they can be fatal. But they also have other consequences (OMS, 2009).

In parallel, in Algeria and in many countries, ruminant pathologies cause serious economic losses for breeders, butchers and sellers, especially in the absence of source control programs for contaminants.

The main objective of this study was to explore the rate of the prevalence of certain ruminant pathologies in Jijel, the health risk and the economic losses that could be caused and finally some factors of variation involved in the incidence of these pathologies. In addition, the purpose of the work is to propose the necessary corrective measures to fight against the sources of pathological transmission in order to preserve public health and favour local production of meat.

\section{Material and methods}

Study zone: The wilaya of Jijel is located in the North-East of the country, on the Mediterranean coast. The chief town of the wilaya is located 350 $\mathrm{km}$ west of the capital, Algiers. The wilaya covers an area of $2.398 \mathrm{~km}^{2}$. It is limited to the North by the Mediterranean Sea, to the East by the wilaya of Skikda, to the West by the wilaya of Bejaia and to the South by the wilayas of Constantine and Mila (Figure 1) (ANIREF, 2011).

It is characterized by the presence of various ruminants among cattle, sheep and goats with a total estimated number of 87942 head (33.88\%), 109336 head (42.12\%) and 62292 head (24\%) respectively (Wilaya monograph, 2014).
During the study period, the average values of the weather conditions in the climatic zone of Jijel (Achouat station) are: $14.56 \pm 1.22{ }^{\circ} \mathrm{C}$ and $3.50 \pm 1.22 \mathrm{~mm}$ respectively for temperature and precipitation (Infoclimat, 2019).

\section{Materials and methods}

In total, six hundred and twenty five animals composed of three types of animal species (five hundred and eleven cattle, seventy-four sheep and forty goats) were examined by a post-mortem inspection for the detection of certain frequent and dangerous diseases on the animal and human health in the central slaughterhouse of Jijel.

Carcasses and fifth quarters (offal) were examined by veterinary doctors under the direction of a major veterinary inspector. The carcasses were examined by a distant visual examination and then a close examination. While red offal (liver, lungs, kidneys) were inspected visually and then palpated and incised.

Days of slaughter of animals from Sunday to Thursday except holidays and non-working days.

In parallel, meteorological data for the region of Jijel (mean temperature and mean precipitation) were retrieved and recorded. They are used to study the factors of variation of pathologies reported by veterinary doctors.

Statistical analysis: Prevalences were calculated by organ and pathology and by study month. 
Table 1. Distribution of the prevalence of pathologies studied

\begin{tabular}{cccc}
\hline Diseases & NAS & NPC & Prevalence (\%) \\
\hline Pulmonary and hepatic hydatidosis & 625 & 6 & 0.96 \\
\hline Tuberculosis & 625 & 0 & 0 \\
\hline Liver fasciolosis & 625 & 77 & 12.32 \\
\hline Cystic kidney & 625 & 1 & 0.16 \\
\hline Abscess & 625 & 23 & 3.68 \\
\hline Total & 625 & 107 & $3.42 \pm 5.19$ \\
\hline Average & & & {$[2.00 ; 4.84]$} \\
\hline CI 95 & & \\
\hline NAS: Number of animals slaughtered; NPC: Number of positive cases, CI95: Confidence interval; ${ }^{* * *}:$ P $<0.0001$.
\end{tabular}

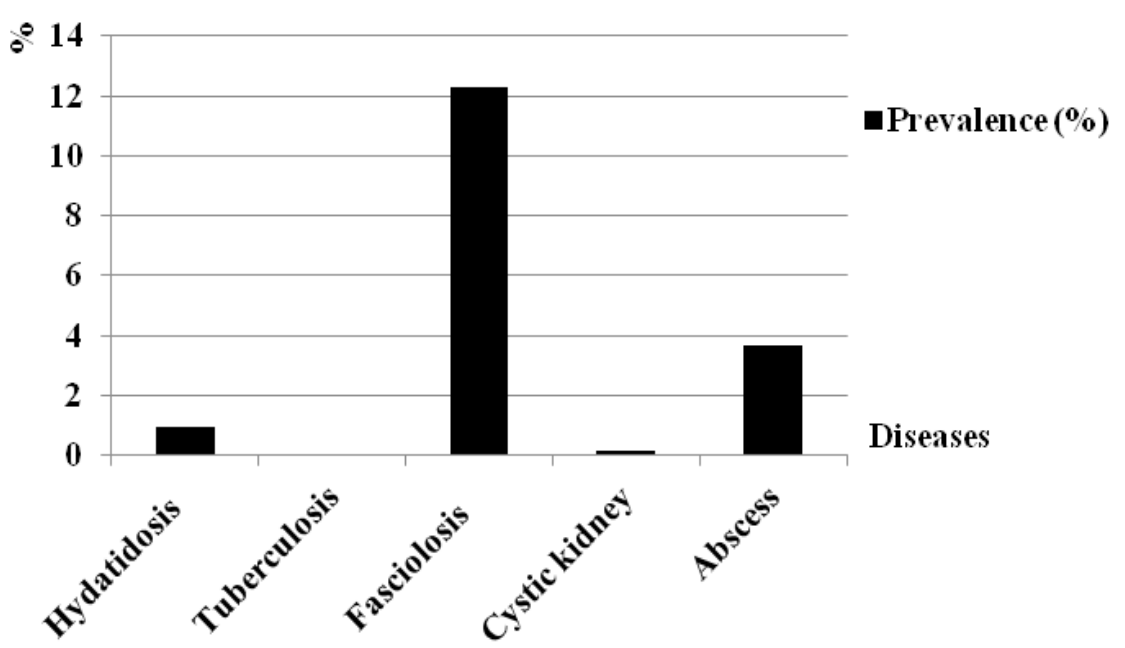

Figure 2. Prevalence of studied pathologies

Affected organs, pathologies, mean temperature and mean precipitation were used as a source of variation.

The chi-square test was used to make an overall comparison between the different pathologies. It is also used to compare the pathologies for each organ. Moreover, it is also used to estimate the significant link between organs affected by the pathologies studied.

The Pearson Correlation Test (Pearson Correlation Matrix) was used to estimate the significant relationship between the different pathologies of each contaminated organ.

The correlation coefficient $(\mathrm{r})$ and the determination coefficient $\left(R^{2}\right)$ were calculated to estimate the link between the pathologies and the mean values of precipitation and average temperature recorded during the half of each study month. A link is considered significant at the $5 \%$ threshold.
Confidence intervals were calculated for the evolution of the average prevalence rate of global pathologies and for the prevalence rate of pathologies of each organ. It was also calculated for the evolution of the average prevalence rate of pathologies between the three affected organs.

Calculations were made using the XLSTAT 2009 software and Microsoft Office Excel® 2007 software.

\section{Results and discussions Overall results}

Table 1 and Figure 2 below represent the distribution of prevalences of suspicious pathologies reported by the organs inspected. The overall prevalence rate is $17.12 \%$.

Depending on the organs, hepatic fascioliasis predominates with an infestation rate of $12.32 \%$; it is followed by abscesses (3.68\%), pulmonary and hepatic hydatidosis $(0.96 \%)$, cystic kidney $(0.16 \%)$ and finally tuberculosis with a rate of $0 \%$. 
Table 2. Distribution of the prevalence rate of diseases according to the organs inspected for slaughtered animals

\begin{tabular}{|c|c|c|c|c|c|c|c|}
\hline Organs & Diseases & NAS (n) & $\operatorname{NPC}(\mathrm{n})$ & Preval & $e(\%)$ & CI95 & SA \\
\hline \multirow{3}{*}{ Lungs } & Hydatidosis & 625 & 3 & 0.48 & \multirow{3}{*}{3.52} & \multirow{3}{*}[2.08;4.96]{} & \multirow{3}{*}{$* * *$} \\
\hline & Tuberculosis & 625 & 22 & 0 & & & \\
\hline & Abscess & 625 & 19 & 3.04 & & & \\
\hline \multirow{4}{*}{ Liver } & Fasciolosis & 625 & 77 & 12.32 & \multirow{4}{*}{13.44} & \multirow{4}{*}[10.77;16.11]{} & \multirow{4}{*}{$* * *$} \\
\hline & Hydatidosis & 625 & 3 & 0.48 & & & \\
\hline & Tuberculosis & 625 & 84 & 0 & & & \\
\hline & Abscess & 625 & 4 & 0.64 & & & \\
\hline \multirow{5}{*}{ kidney } & Tuberculosis & 625 & 0 & 0 & \multirow{3}{*}{0.16} & \multirow{3}{*}[-0.15;0.47]{} & \multirow{3}{*}{ NSD } \\
\hline & Abscess & 625 & 1 & 0 & & & \\
\hline & Cysts & 625 & 1 & 0.16 & & & \\
\hline & \multicolumn{2}{|c|}{ Average } & & \multicolumn{2}{|c|}{$5.71 \pm 6.90$} & & \\
\hline & \multicolumn{2}{|l|}{ CI95 } & & \multicolumn{2}{|c|}{$[3.89 ; 7.53]$} & & \\
\hline SA & & & ** & & & & \\
\hline
\end{tabular}

NSD: Non-significant difference ( $p>0.05$ ); ${ }^{* * *}$ : $\mathrm{P}<0.0001$.

It should be noted that during the study period, the highest prevalence of the pathologies studied was reported during the month of March 2019 (58.88\%).

Statistical analyzes showed that there was a significant difference between the pathologies $(\mathrm{p}<0.0001)$.

Frequency of pathologies according to the affected organs

According to the results obtained, it is noted that the lungs are contaminated by abscesses $(3.04 \%)$ and hydatidosis $(0.48 \%)$. The liver is significantly contaminated by fasciolosis $(12.32 \%)$, followed by abscess $(0.64 \%)$ and hydatidosis $(0.48 \%)$. While, the kidneys are attacked only by cysts $(0.16 \%)$ (Table 2$)$.

Overall, the liver is more contaminated $(13.44 \%)$ compared to the lungs (3.52\%) and the kidneys (0.16\%).

However, two clearly significant differences $(p<0.0001)$ were recorded. The first between the different pulmonary pathologies and the second between the liver pathologies. On the other hand, a non-significant difference was observed between kidney pathologies ( $\mathrm{P}>0.05)$. In parallel, another clearly significant difference $(\mathrm{P}<0.0001)$ was found between the three contaminated organs: lungs, liver and kidneys.

Knowing that each organ contaminated by one of the studied pathologies undergoes a total seizure, this goes to prove that the average daily number of livers seized is $1.88 \pm 1.73,0.07 \pm 0.26$ following the infestation by the fasciolosis and the hydatidosis, respectively.

In addition, the average daily number of lungs seized is $0.07 \pm 0.26$ due to hydatidosis infestation. In addition, the average daily number of lungs and livers seized by the pattern of abscesses are 0.46 \pm 0.71 and $0.10 \pm 0.37$, respectively. While the average daily number of cystic kidney seized is $0.02 \pm 0.16$. Which explains the economic losses.

\section{Correlation study between diseases of the} lungs, liver and kidneys

Table 3 shows the values of $p$-values and the correlation matrices between diseases of the lungs, liver and kidneys. These matrices make it possible to raise the nature of the relationship between the different diseases for each organ.

For the lungs, a weak negative correlation was found between hydatidosis and abscesses $(\mathrm{r}=-0.052, \mathrm{p}=0.746)$. Similarly for the liver, three weak positive correlations were recorded between hydatidosis and abscesses $(\mathrm{r}=+0.179$, $\mathrm{p}$ $=0.263)$, hydatidosis and fasciolosis $(\mathrm{r}=+0.020, \mathrm{p}$ $=0.901)$, abscesses and fasciolosis $(r=+0.057, \mathrm{p}$ $=0.722$ ). While for the kidneys, as they are free of tuberculosis and abscess, which explains the lack of correlation between the cystic kidneys and both pathologies.

Study of the relationship between the average number of cases of the pathologies studied and the two meteorological parameters 
Table 3: P-values and correlation matrix (Pearson) between lung, liver and kidney diseases

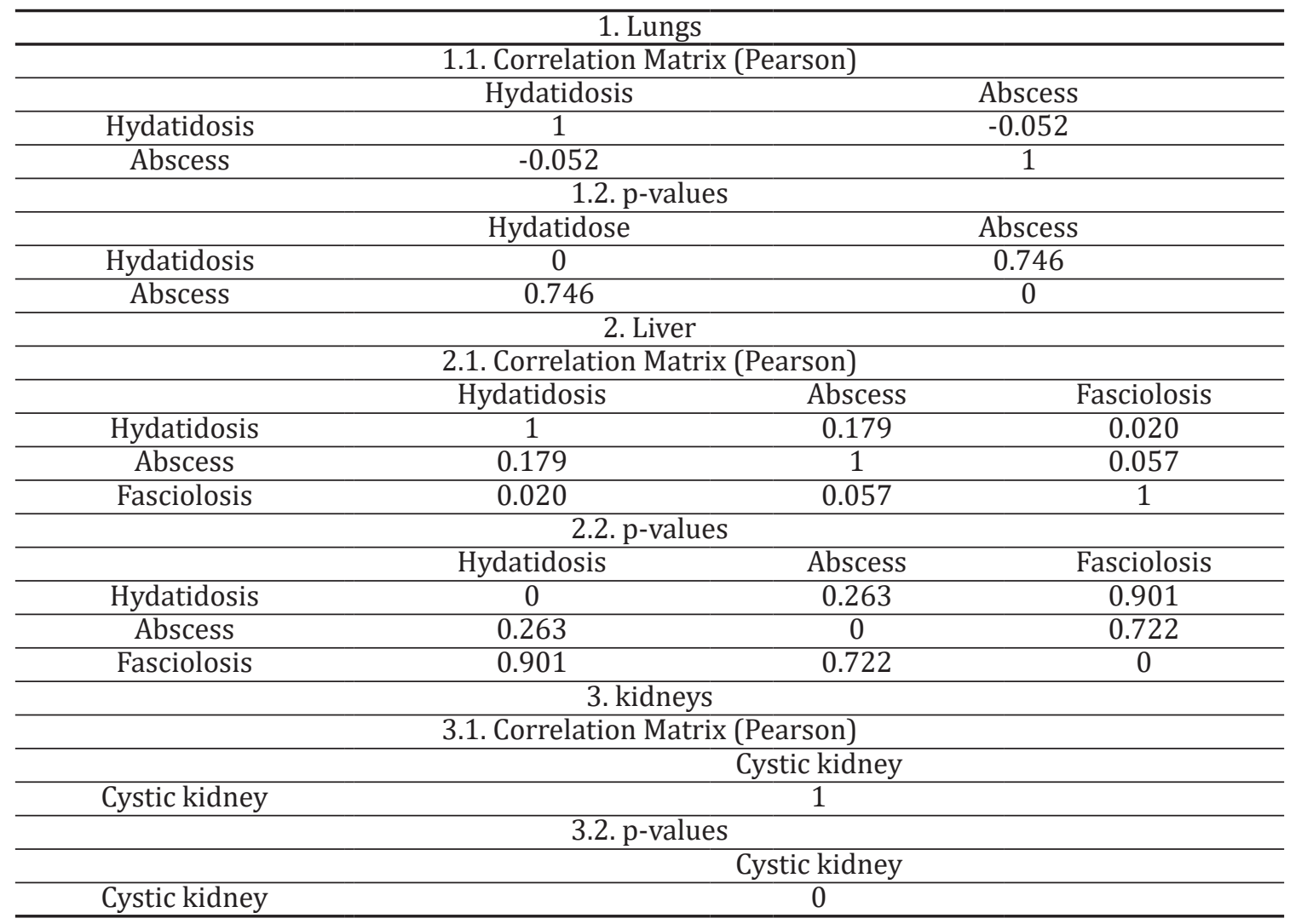

The study of the correlation between the average number of cases of diseases and the mean values of temperature and the precipitation of half of each month showed the existence of six strong correlations. Three positives between hydatidosis and precipitation $\left(\mathrm{r}=+0.58701, \mathrm{R}^{2}=+0.34458\right)$, fasciolosis and precipitation $\left(\mathrm{r}=+0.76469, \mathrm{R}^{2}\right.$ $=+0.58475)$ and abscesses and temperature $(\mathrm{r}$ $\left.=+0.70653, \mathrm{R}^{2}=+0.49919\right)$ and three negative between fascioliasis and temperature $(\mathrm{r}=$ $\left.-0.88034, R^{2}=+0.77500\right)$, cystic kidneys and temperature $\left(\mathrm{r}=-0.55568, \mathrm{R}^{2}=0.30878\right)$ and cystic kidneys and precipitation $\left(\mathrm{r}=-0.56818, \mathrm{R}^{2}\right.$ $=+0.32283$ ) (Table 4).

The main objective of this study is to evaluate the prevalence rate of certain diseases that most often affect the organs of the fifth-quarter (offal) most consumed by Algerians such as the liver, kidneys and lungs. Then, to study the influence of the average temperature and the average precipitation on the contamination rate.

Exploitation of the obtained results has made it possible to notice the importance of certain zoonotic diseases which cause economic losses by seizures of the organs during contamination and constitute a risk on public health thereafter. Our results showed losses in livers, lungs and kidneys following contamination by the pathologies studied. In addition, the highest prevalence was observed during the month of March 2019 (58.88\%). In addition, according to the organs, our results show that the liver $(13.44 \%)$ is the most contaminated compared to the lungs (3.52\%) and the kidneys $(0.16 \%)$. In addition, the most common pathologies with localization in the liver were fasciolosis $(12.32 \%)$, followed by abscesses $(0.64 \%)$ and hydatidosis $(0.48 \%)$. While the lungs more often contaminated with abscess $(3.04 \%)$ followed by hydatidosis $(0.48 \%)$. On the other hand, the kidneys are free from tuberculosis and abscesses. There is only cystic kidney with a rate of $(0.16 \%)$.

These results showed the importance of fasciolosis compared to the other pathologies studied. This pathology leads to seizures of livers at slaughterhouses and therefore leads to economic losses. This is consistent with other studies that have shown the economic importance 
Table 4. Correlation between the average daily number of positive cases of the pathologies studied and the average values of the two meteorological factors

\begin{tabular}{ccc}
\hline Relationship between parameters & $\mathrm{r}$ & $\mathrm{R}^{2}$ \\
\hline HD-TS & +0.01689 & +0.00029 \\
\hline HD-PR & +0.58701 & +0.34458 \\
\hline FC-TS & -0.88034 & +0.77500 \\
\hline FC-PR & +0.76469 & +0.58475 \\
\hline AB-TS & +0.70653 & +0.49919 \\
\hline AB-PR & +0.27335 & +0.07472 \\
\hline CK-TS & -0.55568 & +0.30878 \\
\hline CK-PR & -0.56818 & +0.32283 \\
\hline HD : Hydatidosis ; FC : Fasciolosis ; AB : Abscess ; CK : Cystic Kidney ; TS : Temperature ; PR : Precipitation ; : Correlation
\end{tabular}

coefficient ; $\mathrm{R}^{2}$ : Coefficient of determination

of fascioliasis (Boucheikhchoukh et al., 2012; Aissi et al., 2009).

Overall, the rate of total infection prevalence is $17.12 \%$ and hepatic fascioliasis is the most common pathology (12.32\%). Our results of fasciolosis are reproached to those of Bendiaf (2011) in Skikda (13.2\%). On the other hand, they remain inferior to those of Aissi et al. (2009) in some cattle farms in Northern central Algeria with an average prevalence of $18.5 \%$ and Mekroud et al., (2004) on slaughtered cattle (27.0\%). It should be noted that animal fascioliasis is considered as a serious disease mainly because of the important economic loss that it generates. Indeed, in farm animals, it leads to a drop in production, a decrease in traction capacity in the buffalo, seizures of livers in slaughterhouses and sometimes the mortality of infested animals. In addition, fascioliasis is a zoonosis, with humans infesting by consuming plants growing in aquatic or humid environments (Chauvin et al., 2007). In addition, the region of Jijel is classified as a wetland in Algeria since it is very rich in water resources such as dams, lakes and rivers. This favors the progress of the evolutionary cycle and parasitic infestation. In addition, the onset of the condition and the increase in prevalence during the spring-fall seasons is related to the lack or absence of any preventive treatment by campaign companions and an effective and serious strategy of preventive vaccination before the beginning of the two seasons (Merdas Ferhati, 2015).

Regarding abscesses, our results showed a prevalence rate of $3.04 \%$ and $0.64 \%$ respectively for pulmonary and hepatic abscesses. These results are clearly lower than those obtained by Blaise (2001) in Haiti with prevalence rates of
$2.7 \%$ for the liver of cattle, but remain higher for pulmonary abscess in cattle $(0.26 \%)$.

According to Figueroa and Maier (2007) and Malone and Fee (2006), cited by Alloui et al., (2008), several authors claim that abscess disease is a pathology found in all intensive livestock farming. In parallel, according to Pearson and Maas (1990), cited by Achard (2005), the majority of cases of hepatic abscess in cows are related to clinical or subclinical ruminal acidosis. Most of the time, liver abscess goes unnoticed and is nothing but slaughterhouse discoveries. That does not prevent that they are at the origin of a fall of production.

In addition, poor hygiene, precarious shelters and the breeding of several animal species on the same farm seem to be the most determining factors in the onset of the disease (results available but not shown here) (Alloui et al., (2008).

With regard to hydatidosis, in Algeria, dogs are the main reservoir of Echinococcus granulosus infection for domestic animals and for humans (intermediate hosts) (Benchikh-Elfegoun et al., 2008). Our results $(0.96 \%)$ are clearly lower than those obtained by Boucheikhchoukh et al., (2012) in an epidemiological survey at the level of two slaughterhouses in the region of El Tarf (Algeria) which have been reported to have a rate of $(30.9 \%)$ and Mrifag et al., (2013) in an epidemiological study on bovine hydatidosis in North-Western Morocco with an infestation rate ranging from $42.9 \%$ in summer to $92.6 \%$ in winter. On the other hand, they remain higher than those found by Bichet and Dorchies (1998) (cited by Mrifag et al., 2013) in Midi-Pyrénées, where the prevalence rate for the period $1994-1996$ was only $0.28 \%$ for animals. 
According to Boucheikhchoukh et al., (2012), overall, a prevalence of $30.9 \%$ shows the persistence of a highly contaminated environment by the feces of dogs that contain infective embryonated eggs, which underlines the insufficient control of the infection in definitive host with a high number of dogs roaming around the herds.

Moreover, at present, the existence and persistence of favorable conditions for the contamination of dogs (family slaughter, illegal slaughter, the presence of stray dogs) justify the high infestation rates found in our study in urban areas. This situation makes the urban cycle more and more important (Benchikh-Elfegoun et al., 2008).

The study of the relationship between the average number of cases of pathologies and the mean values of temperature and precipitation revealed six very high correlations $(r>0.5)$. On the one hand, three are positive between hydatidosis and precipitation $\left(\mathrm{r}=+0.58701, \mathrm{R}^{2}=+0.34458\right)$, fasciolosis and precipitation $\left(\mathrm{r}=+0.76469, \mathrm{R}^{2}\right.$ $=+0.58475)$ and abscesses and temperature ( $\left.r=+0.70653, R^{2}=+0.49919\right)$, and on the other hand three are negative between fasciolosis and temperature $\left(\mathrm{r}=-0.88034, \mathrm{R}^{2}=+0.77500\right)$, cystic kidneys and temperature $\left(\mathrm{r}=-0.55568, \mathrm{R}^{2}\right.$ $=+0.30878$ ) and cystic kidneys and precipitation $\left(\mathrm{r}=-0.56818, \mathrm{R}^{2}=+0.32283\right)$. This confirms the relationship between the etiological agents of the pathologies studied and the meteorological indicators (precipitation and temperature). Therefore, with the existence of favorable climatic conditions for survival and development of the etiological agents of a disease promote a smooth evolutionary cycle and therefore emergence of a disease afterwards.

In parallel, the region of Jijel is considered among the rainiest regions of Algeria. It is characterized by a Mediterranean climate, rainy and cold in winter, hot and humid in summer. Temperatures vary between $20^{\circ} \mathrm{C}$ and $35^{\circ} \mathrm{C}$ in summer at $5^{\circ} \mathrm{C}$ to $15^{\circ} \mathrm{C}$ in winter. The rainy season lasts about six months (ANDI, 2013). Which justifies the presence of favourable conditions for the etiological agents survival, the transmission and the later appearance of the diseases.

Finally, it is interesting to know the prevalence of pathologies in animals slaughtered in Algerian slaughterhouses, because they cause significant economic losses in meat and constitute a major risk to the health of consumers. In addition, improved enforcement and prevention measures need to be called for. It is recommended to apply preventive treatments regularly to reduce the number of positive cases and to eradicate the pathology afterwards.

\section{Conclusion}

The results of this study confirm the importance of the involvement of certain internal organs by fasciolosis, abscesses and hydatidosis. The distribution of these diseases varies according to the contaminated organs. The liver is more affected by fasciolosis followed by abscesses and hydatidosis, while the lungs are affected mainly by abscesses followed by hydatidosis. In contrast, there are only cystic kidneys as a disease that attacks the kidneys. This translates into a significant economic loss due to the presence of various pathologies and may constitute a risk to human health in case of consumption of contaminated organs and insufficiently cooked.

In addition, it should be noted that the pathologies studied are related to certain meteorological parameters such as temperature and precipitation. Itis thereforenecessary to setupa preventive program to eradicate these pathologies and reduce the number of condemned organs, by acting on the causal agents and the life cycles of the parasites, in order to stop the transmission of etiological agents. Sensitization and extension of the population at risk and other actors in the sector is mandatory. In addition, effective veterinary inspections at the slaughterhouse level are mandatory in order to minimize the maximum economic losses in Algerian slaughterhouses and reduce the importation of foreign meat.

Acknowledgments. The authors thank all the staff of the Jijel abattoir.

\section{References}

1. Aissi M, Harhoura Kh, Gaid S and Hamrioui B (2009). Etude préliminaire sur la prévalence de la fasciolose due à Fasciola hepatica dans quelques élevages bovins du nord Algérien (la Mitidja). Bull Soc Pathol Exot., 102 (3) : 177178.

2. Alloui MN, Ayachi A, Alloui N, Tlidjane M, Kaba J (2008). Prévalence de la maladie des abcès des petits ruminants dans la région de Batna (Algérie). Renc. Rech. Ruminants, $15,87$.

3. ANDI (2013). Wilaya de Jijel. Invest in Algeria, $24 \mathrm{p}$. http://www.andi.dz/PDF/monographies/Jijel.pdf 
4. ANIREF (2011). Rubrique Monographie Wilaya. Wilaya de Jijel, 5 p. http://www.aniref.dz/monographies/ar/jijel. pdf

5. Benchikh-Elfegoun MC, Benakhla A, Bentounsi B, Bererhi H, Sfaksi A, Dumon H, Piarroux R (2008). Évaluation de l'infestation par Echinococcus granulosus des chiens par le test E.L.I.S.A. Sciences \& Technologie, 27 : 15-22. revue. umc.edu.dz/index.php/c/article/download/362/469

6. Bender A (1992). Meat and meat products in human nutrition in developing countries. Animal Production and Health Division and the Food Policy and Nutrition Division of FAO, Rome, 122 p. https://pdfs.semanticscholar.org/7d 04/4844464d3ef3ebebbf9d10a66d95387e0f36.pdf

7. Bendiaf H (2011). Contribution à l'étude de la distomatose à Fasciola hepatica (Linné, 1758) : Aspects parasitologique et sérologique. Mémoire de Magister, Université Mentouri Constantine, Département des Sciences Vétérinaires, 177 p. https://bu.umc.edu.dz/theses/veterinaire/BEN5981. pdf

8. Bichet H, Dorchies P (1998). In : Mrifag R, El Kharrim Kh, Belghyti D, Laamri M and Boukbal M (2013). Étude épidémiologique sur l'hydatidose bovine dans le nordouest marocain. Bull. Soc. Pharm. Bordeaux, 152 (1-4) : 7-18.

9. Blaise F (2001). Prévalence et fréquence des lésions parasitaires du foie et du poumon des ruminants en Haïti. Revue Méd. Vét., 152 (3) : 269-274. https://www. revmedvet.com/2001/RMV152_269_274.pdf

10. Boucheikhchoukh M, Righi S, Sedraoui S, Mekroud M and Benakhla A (2012). Principales helminthoses des bovins : enquête épidémiologique au niveau de deux abattoirs de la région d'El Tarf (Algérie). Tropicultura, 30 (3) : 167172. http://www.tropicultura.org/text/v30n3/167.pdf

11. Chauvin A, Zhang W and Moreau E (2007). La fasciolose des ruminants : immunité, immunomodulation et stratégie de prévention. Bull. Acad. Vét., France, Tome 160 - N2 2 : 85 - 92.https://www.academie-veterinaire-defrance. org/fileadmin/user_upload/Bulletin/pdf/2007/ numero02/85.pdf

12. Figueroa JP, Maier NL (2007). In : Alloui MN, Ayachi A Alloui N, Tlidjane M and Kaba J (2008). Prévalence de la maladie des abcès des petits ruminants dans la région de Batna (Algérie). Renc. Rech. Ruminants, 15, 87.
13. Infoclimat (2019). Climatologie de l'année 2019 à Jijel, Achouat - Infoclimat. http://www.infoclimat.fr/ climatologie/annee/2018/jijel-achouat/valeurs/60351. html

14. Lecerf JM (2014). La place de la viande dans la nutrition humaine. Intérêt nutritionnel et effets sur la santé de la consommation de viande. Viandes \& Produits Carnés, 1 5.

15. Malone FE, Fee SA (2006). In : Alloui MN, Ayachi A, Alloui $\mathrm{N}$, Tlidjane $\mathrm{M}$ and Kaba J (2008). Prévalence de la maladie des abcès des petits ruminants dans la région de Batna (Algérie). Renc. Rech. Ruminants, 15, 87.

16. Mekroud A, Benakhla A, Vignoles P, Rondelaud D and Dreyfuss G (2004). Preliminary studies on the prevalences of natural fasciolosis in cattle, sheep, and the host snail (Galba truncatula) in north-eastern Algeria. Parasitol. Res., 92 (6) : 502-5.

17. Merdas Ferhati H (2015). Etude épidémiologique, biochimique et immunologique de la Fasciolose chez les bovins (race locale) dans la région d'Annaba. Thèse de Doctorat Es Sciences, Université Badji Mokhtar - Annaba, Département de biologie, 92 p. http://biblio.univ-annaba. dz/wp-content/uploads/2015/12/these-Ferhati-Habiba. pdf

18. Mrifag R, El Kharrim Kh, Belghyti D, Laamri M, Boukbal M (2013). Étude épidémiologique sur l'hydatidose bovine dans le nord-ouest marocain. Bull. Soc. Pharm. Bordeaux, 152(1-4) : 7-18.

19. OMS (2009). Hygiène des denrées alimentaires. Quatrième édition. Codex Alimentarius. Organisation des nations unies pour l'alimentation et l'agriculture, Rome, $142 \mathrm{p}$.

20. Pearson EG, Maas J (1990). In : Achard DT (2005). Exploration des affections hépatiques chez la vache laitière - Apport des examens complémentaires, Détermination des valeurs usuelles sanguines en ASAT, GDH, $\gamma \mathrm{GT}$ et bilirubine totale, Application au diagnostic de l'ehrlichiose bovine. These pour le diplôme d'Etat de Docteur vétérinaire, Ecole Nationale Vétérinaire de Nantes, 105 p.

21. Wilaya Monograph (2014). In : Annuaire économique des wilayas (2018). Secteurs économiques : agriculture et élevage dans la wilaya de Jijel. http://monographies.caci. $\mathrm{dz} /$ index.php?id=665 